\title{
Queer Film Culture in the COVID-19 Era
}

\author{
Nordic and Baltic LGBTQAI+ Film Festival Survey
}

LGBTQAI+ FILM FESTIVALS are key sites of queer world-making (Berlant \& Warner 1998, Muñoz 2009). Making visible non-normative lives and alternative audiovisual cultures, they create counterpublics: spaces and communities where transgressive notions of "identity, intelligibility, publics, culture, and sex" (Berlant \& Warner I998, 548) are envisioned, imagined and enabled. At the same time, LGBTQAI+ festivals - like all film festivals - are an integral part of cinephilia and venues for challenging mainstream cinema cultures (Loist \& Dawson 2018). As cultural events, they serve as both meeting points for filmmakers and audiences and as social movements and market niches. They are sites for both political struggles and community building. As such, film festivals have a significant symbolic value and often attract high media attention, but they are also vulnerable to changing political climates, cultural policies and economic pressures.

In the Nordic and Baltic countries, the number of LGBTQAI+ film festivals has risen during the last few years, although there is also a history of festivals spanning several decades. MIX Copenhagen was founded as early as 1986, but even earlier, gay and lesbian film weeks and one-off events took place in contexts such as film clubs, cinemateques, gay and lesbian associations and women's film festivals. While 
linking to the international gay and lesbian film festival movement that started in the r970s (Loist \& Dawson 2018), today's festivals use different naming strategies, highlighting "queer" or "trans" - or choosing names that indicate a broader sense of alternative cinema culture (Mix, Fusion, Vinokino, Side by Side). Various acronym combinations, such as LGBTQAI+, are used by festivals as well as in academic research (including us here) as a broad categorization of this festival culture. The naming question is subject to continuous debate (Edenheim 2020), reflecting changing notions of community, political stakes and cultural contexts.

In September 2020 we, the editors of this special issue, contacted many of these festivals - both the pioneering and the more recent ones - to take stock of where they stand at the moment. Our goal with this survey was to highlight the multitude and diversity of LGBTQAI+ film festivals in the Nordic and Baltic countries, their divergent histories, contexts and resources. At the same time, we wanted to gather information about the potential struggles that the present pandemic situation imposes on these festivals.

We asked all the festivals we contacted the following questions:

I. How would you describe the profile of this festival, its history, politics and position within its national as well as international context?

2. How has the Covid-I9 pandemic affected this festival?

3. How do you see the future of queer cinema culture and this and other film festivals' role in it?

The festivals and festival representatives who answered were - in order of seniority, starting from the longest running ones - MIX Copenhagen/Andrea Coloma (DE), Oslo/Fusion International Film Festival/Bård Ydén (NO), Vinokino/Antti Tiainen and Taija Ahlstedt (FI), Side by Side St. Petersburg/Manny de Guerre (RU), Malmö Queer Filmfestival/J. Seipel (SE), Trans Film Fest Stockholm/collective response (SE), Festheart Estland/Keio Soomelt (EE). 


\section{Q: How would you describe the profile of this festival, its history, politics and position within its national as well as international context?}

\section{COPENHAGEN}

MIX COPENHAGEN was founded in 1986 and was then called the Copenhagen Gay Film Festival. We are now the leading queer film festival in the Nordic countries, the third-largest festival in Denmark, and one of the oldest LGBTQ+ film festivals in the world.

We want to influence and be part of the gender debate locally and internationally by screening films that push and break societal norms and boundaries of gender and sexuality. Therefore, we do not shy away from films such as Daniel's World (screened in 2015) and Jumbo (screened in 2020) that present topics of pedophilia and objectophilia, respectively. In 2018, we decided to implement a boycott of films that cast cisgender actors to play transgender characters. After receiving criticism for years and following the discussions that transgender people in the film industry have had, we decided that the best way to support their plight was by implementing the boycott.

As a film festival, MIX COPENHAGEN is one of the last links in the film industry chain. This means that we have the power to decide which films make it to a wider audience. By boycotting films that cast cisgender people to play transgender characters, we are part of determining which films get distribution. The boycott is still in place today.

\section{Oslo/Fusion Film Festival}

Oslo/Fusion Film Festival was founded in 1990 and is Norway's only film festival dedicated to stories of, by and for the LGBTQIA+ community. It is also one of Norway's longest running film festivals and the largest festival dedicated to promoting diversity, equality and education through entertainment - with film screenings, panel discussions and related events. By its content alone, the festival is political, but its position remains somewhat marginalized within the broader festival community, thus it is still relevant and necessary. 


\section{Vinokino}

The festival started in 1992 as a lesbian and gay film festival, but nowadays it is more of a queer film festival. Vinokino is the only LGBTIQA+ film festival in Finland and for many, it has been the only place where they can watch LGBTIQA+ films. We have screenings in Turku and Helsinki and we also offer our film selection to other cities. Additionally, Vinokino shows documentaries in the Vinokino Docs, a free screening series outside the festival period. The festival includes cultural and social functions: during a normal year, we have an evening party in both Turku and Helsinki and hold screenings at Turku Pride and Helsinki Pride.

Vinokino provides a safe place for LGBTIQA+ people to meet each other and enjoy movies. The festival also promotes and highlights the best of independent queer film from all around the world. When we choose our films, we try to keep in mind the audience: we want everyone to have something they can relate to.

Vinokino has relied mainly on volunteers, but in the last three years, we have been able to also hire staff. Turun Seudun Seta ry (the Association for Sexual Equality in the Turku region) is the organization behind Vinokino, and we get most of our income from grants. 202 I will be our 3oth year running, and we hope to be able to celebrate the long history of Vinokino with extra special screenings and a seminar.

\section{Side by Side}

In Russian society, there is a great deal of homophobia and transphobia. LGBTQ+ people face unprecedented levels of intolerance and prejudice. The Russian government does nothing to stop discrimination and is in fact a key protagonist, giving license to even greater expression of hate and discrimination within society towards LGBTQ + groups.

Side by Side, founded in the summer 2007 , set out to challenge this situation. Through film screenings, panel discussions, seminars, workshops and exhibitions we seek to create a positive dialogue with society in order to challenge negative stereotypes about LGBTQ+ people and inform, educate and enlighten people on issues relating to sexual ori- 
entation and gender identity. We aim to foster respect for the human rights of LGBTQ+ persons and fundamentally to bring about greater tolerance, broader acceptance and visibility for LGBTQ+ groups in Russian society.

Side by Side is a very much needed project. The public space to discuss LGBTQ + issues is shrinking, and Side by Side is one of the very few organizations that provide alternative information platforms, offer discussion and debate in public, and educate and challenge directly homophobic opinions. In addition, we focus strongly on individual participation and citizen engagement. In our call to action, we provide audiences, volunteers and supporters with the opportunity to practice their rights to freedom of association, freedom of peaceful assembly and freedom of expression first hand. Through our work, we are helping to create individuals who are interested and proactive in LGBT and human rights issues, not indifferent to the erosion of their rights nor the rights of others.

\section{Malmö Queer Film Festival}

Malmö Queer Film Festival (MQF) is the oldest running queer film festival in Sweden. It was established as a community-based film festival and became a central queer political and cultural space within the LGBTQIA+ community in Malmö and the surrounding region. As a low budget, volunteer-driven, queer film festival, MQF is produced every year by a group of people who have an interest in queer film culture. The members of the group change, and their number varies up to eight people, with a stable core group of two. Every member temporary or more permanent - brings different interests, experiences, abilities and approaches to the group. This implies that MQF is always changing with regard to content, topics, and form. Constant change creates friction that keeps the festival up to date with the ever-changing LGBTQIA+ community it draws on and is meant for. As a result, MQF has been and is constantly asking questions like: What is the LGBTQIA+ community? Who is seen and accepted as a member of the LGBTQIA+ community? Who has access to the community, both 
physically and based on varied experiences, abilities and backgrounds? Who sets norms within the community? Which norms should be challenged and in which ways?

Malmö Queer Filmfestival began in 2007, when Folkets Bio Malmö and Lund (the local chapters of the non-profit cinema association in Sweden) screened films together with Regnbågsfestivalen (Pride) in Lund and Malmö, and became an annual festival in 2009. Since its beginnings, MQF has always collaborated with other, mostly non-profit organizations. MQF is owned by Folkets Bio Malmö (FBM). That means that MQF has a small but guaranteed budget to spend every year without needing to apply for money and with no questions asked. In return, the MQF team provides FBM with guaranteed "queer content" - a condition or at least an advantage when seeking funding from many public funding bodies. The relation between FBM and MQF is based on trust, with MQF being the weaker party: if FBM should decide that there is no money for the queer film festival - for example as result of lesser earnings after COVID-I9 - we do not have any say.

\section{Trans Film Fest Stockholm}

Trans Film Fest Stockholm has taken place since 2015. Our festival of films, talks and events is centered on marking the Trans Day of Remembrance on November 20. The festival is a space for our community to come together in solidarity, grief, and power. During the festival, we strive to create safer spaces and engage in activism and communitybuilding through film. We center voices and experiences that are marginalized and silenced in mainstream representations and normative accounts of Trans and gender-diverse people.

We make space for stories that reflect the complexities of our experiences, and films made by and for our community are our priority. Over the years we have worked to build relationships with other queer and Trans organizations in Sweden and abroad. Most recently, we hosted activists from Transformations - Trans Film Festival Berlin who brought highlights from their festival to our audience in 2019 . 


\section{Festheart}

Festheart (EST) started in 2017 and is the only annual LGBT+ film festival in the Baltic countries. During the first three years, we offered one three-day festival in Rakvere in the beginning of October. This year we had one weekend (October 2-4) in Tartu and one weekend (October 9-II) in Rakvere. Every year we screen around ten new LGBT+ movies in Estonia. Some of them are later screened in other cinemas, but our festival is often the only opportunity to see them in the Baltic countries. At the beginning, it was quite difficult to even organize the festival, as the local municipalities did not accept us, and there were a lot of fights. Now it seems that everybody has calmed down, and the situation is better. However, we are very anxious about next year: if there is a referendum in Estonia about adding "traditional marriage" to the constitution, it will take place one week after the festival and create a lot of debate and unrest. Unfortunately, at the moment, the Estonian government is becoming increasingly conservative, and cooperation is very difficult. However, we will survive, as we always do.

\section{Q: How has the COVID-19 pandemic affected the festival?}

\section{COPENHAGEN}

We usually conduct screenings and events throughout the year, before and after the festival. Some of these were canceled this year due to the COVID-r9 pandemic. Nevertheless, we managed to have screenings before the festival as well as the physical festival, where we faced two main challenges: firstly, the cinemas are running at 50 per cent of their capacity, and secondly, people are scared of coming to the cinema due to the pandemic.

Due to COVID-I9 related restrictions, our events could only host a maximum of 50 people. We decided to proceed with most of them, regardless of the restrictions, and keep our MIX Lounge open, because our festival has the capacity to create spaces for the community and we knew that the LGBTQ+ community in Copenhagen needed a space that we could provide. As expected, all of our events sold out and we therefore decided to live stream most of them. Regrettably, we had to 
cancel our biggest and most popular events, the opening and closing ceremonies. To compensate, we decided to launch our very first online festival, which took place November 2-I I, after the physical festival. We wanted to reach those who were not able to participate in the physical festival, as well as extend our reach to the whole of Denmark. We made a selection from our physical festival program, and it was a success!

\section{Oslo/Fusion Film Festival}

We had to cancel most of our initial plans to celebrate the festival's 3 oth anniversary this year. We scheduled all our screenings in the cinema, but at less than 50 per cent of the capacity. We were unable to bring filmmakers and guests from abroad to the festival, so for the most part, we were only able to do screenings this year. In addition to the main festival, we also arranged a digital festival October 2I-30. At a time when anyone working with cultural activities is affected financially by the pandemic, we wanted to give back to the community, so we split roo per cent of the proceeds from ticket sales between all filmmakers with a film in the digital edition of the festival.

\section{Vinokino}

COVID-I9 has brought complications and overall uncertainty to the festival. Then again, Vinokino has been quite lucky compared to many other events. In Turku, we were able to sell half of the tickets available, but sadly, we had to cancel screenings in Helsinki altogether with very short notice. So financially, this year has been somewhat of a disaster, but we are hoping for a better festival next year and are looking into the possibility of arranging the festival in Helsinki in the spring or summer of 202 I.

\section{Side by Side}

COVID-rg has meant limited possibilities of public gathering, and we had to cancel the Moscow festival. In Saint Petersburg, the authorities used the pandemic as an excuse to shut down the offline part of the festival. ${ }^{\mathrm{I}}$ Public gathering is important for LGBTQ+ people here, because it enables them to be visible in a safe, public space and gives 
a sense of community. Online events, discussions and screenings were organized, but many audience members noted that online activities are not the same. They wished for possibilities of offline events.

\section{Malmö Queer Film Festival}

As MQF is a steady part of Folkets Bio Malmö's yearly schedule, with its own small budget, the effect of the COVID-rg pandemic has been modest. The 2020 festival was scheduled for April as usual. The work with the film program, guests, Q\&A events and the poster had been almost completed when we in March, together with FBM, decided to cancel the festival. Some of the main films had already been paid for, but we were able to negotiate future screenings with the same conditions. Even when we cancelled the festival itself, we discussed the possibility of arranging a Queer Film Day later in the autumn and set the preliminary date to November at Folkets Bio Malmö.

When the Panora cinema of FBM opened again in the summer, we fixed that date and are now (October 2020) preparing the Queer Film Day with our regular program "Local Heroes" - queer short films from the region - and one feature film, Walking With Shadows, an adaption of Jude Dibia's book with the same title. Jude Dibia was "fristadförfattare" [a sheltered writer-at-risk] in Malmö 2015-2017.

The fact that we have been working with a limited budget over the past few years turned out to our advantage, as we have not lost any money due to the cancelled festival. We have not been forced to pay back any funding or lost any sponsors. Being a small, community-based festival with limited financial resources means we also have limited possibilities, but greater independence. Since MQF is mostly built on the commitment of queers, it is a stable feature of the community as long as there are queers who want to be involved and "do" the festival.

\section{Trans Film Fest Stockholm}

The impact of the COVID-r9 pandemic has been massive on our small, grassroots collective. The current circumstances highlight how vulnerable volunteer-run organizations such as ours are - not only financially, 
but also in terms of the distinct drop in energy and momentum when we are isolated from each other.

We did not host our film festival in 2020. Already marginalized groups such as Black people, people of colour, disabled and chronically ill people have been hit harder by the COVID-I9 pandemic, and this made it impossible to justify hosting a physical edition of the festival only. In addition, a financial source we rely on was restructured due to COVID-I9, leaving us without funding and limiting our other options. We know that our community is suffering due to the isolation and loneliness of these times, and we are trying out new ways of engaging and creating accessible Trans spaces.

\section{Festheart}

Because of COVID-I9, we had to make some practical changes (longer intermissions between the films to clean and ventilate the cinema, selling only 50 per cent of seats etc.), but the biggest problem was global rather than local: because of global problems in the film industry, it became more difficult to get films to screen. And because of travel restrictions, it was hard to get guests and performers from other countries. Of course, we also had a smaller audience, as many people were afraid to attend, but the attendance numbers were still quite good.

\section{Q: How do you see the future of queer cinema culture, and this and other film festivals' role in it?}

\section{COPENHAGEN}

As LGBTQ + themes make their way into mainstream cinema, we believe our role is to ensure that stories not palatable to mainstream audiences will still be seen and supported. Film festivals like ours have a duty to look into independent film and what the industry is doing, and to bring it to the audiences. We believe we have a responsibility to inspire people to come to their local cinemas, although we do see some changes underway. As for the changing nature of culture consumption - whether it is due to the pandemic or to new consumer behavior - we have already witnessed the 
quick pivoting many festivals did in the face of lockdowns earlier this year. Thus, we believe that film festivals, as organizations and cultural platforms, will adapt and continue to be important players in the film industry.

\section{Oslo/Fusion Film Fest}

Assuming you mean independently of the pandemic, the queer film community is thriving, and there are more stories being told than ever. With easy access to equipment, and more and more filmmakers emerging, there is no lack of content. Festivals are still a great platform, not only for filmmakers to showcase their films, but also for making connections, exchanging ideas, and inspiring collaborations. And we are happy and lucky to be part of this community.

\section{Vinokino}

In the future, we will probably see more queer films in the mainstream, but there will always be independent films that will only be shown at smaller festivals like Vinokino. Also, the diversity in films and among filmmakers seems to be increasing.

\section{Side by Side}

Queer film culture will expand and even more stories will be told. I think we are only just seeing the beginning, and the possibilities are endless, with more and more narratives being put on screen. I think LGBTQ + and feminist projects will receive more funding and generally become a greater presence across the mainstream landscape. LGBTQ+ festivals will continue to be relevant and a necessity - there are always negative forces in place that will try to push back progress. There will always be a need for LGBTQ+ festivals as a platform for voices that are considered alternative or different.

\section{Malmö Queer Film festival}

"Queer" cinema culture and film festivals can now be found in many almost all - countries in the world, and queer films and film festivals differ as much as LGBTQIA+ communities do. 
What we in the Global North/West have seen since the late I99os and early 2000 is a differentiation within the LGBTQIA+ community. Parts of the community have been and are fighting and lobbying to become a part of the norm/al society, with questions of gay marriage, adoption laws, sex/gender affirming legislation, anti-discrimination laws and practice, gays and lesbians within the workplace etc. as their central issues.

At bigger Pride events, including the upcoming World Pride in Copenhagen and Malmö, we can see a commercialisation, neo-liberalisation and "norm"alisation, including pinkwashing, by businesses and institutions that have no interest in more radical queer content. As a reaction, those parts of the "LGBTQIA+" acronym that are not included in or are actively excluded from society - queers of colour/QPoC, refugees and asylum seekers, intersex, non-binary trans/genderqueer people, queers with non-normative dis/abilities, poor queers, working class queers - or just people with a more radical political understanding of the word queer, have built up "alternative", anti-normative/normfucking movements.

Alongside a gradual normalisation of LGB and some T-issues, we are simultaneously experiencing a strong backlash connected to a growing right-wing, populist development in countries like the US, Brazil, and Chechnya, as well as in European countries - most obviously Hungary and Poland but not least Sweden - where Prides get attacked, rainbow flags burnt, and queer activists receive death threats. In the Global South and in migrant and queer communities of colour, we can see new ways of creating communities around sexuality and gender that are different from the dominant "Western" LGBTQIA+ discourses.

Parallel developments can be seen in queer film production and screenings. There are more and more commercially successful films on the market. But for a film to become commercially successful, it has to address and please a large enough audience. That is rarely true for radical, norm-breaking (in terms of both content and aesthetics) films. Some of the bigger queer film festivals aim to satisfy more normative tastes and expectations. Others, sometimes newly founded, often small- 
er queer film festivals, keep asking radical questions about who "is the community anyway", focusing on issues of racism, ableism, homophobia and transphobia, fatphobia, sexism etc. within the community. That is what MQF is about and will continue to be about in the future.

\section{Trans Film Fest Stockholm}

We think that Trans and queer cinema has a bright future. Every year we get hundreds of submissions - this year nearly 500 - from filmmakers around the world. We are heartbroken that we had to cancel our 2020 festival and could not share some of the incredible Trans films produced by our international community. We are committed to challenging the mainstream representation of Trans identities with content that truly reflects our lives. This is a role that our festival and other Trans (and queer) festivals play and will continue to play. Trans "stories" have become popular, but are often told without the input and voices of, or true care for, the Trans people involved. As we see it, collaborations among actors and associations engaged in organizing and supporting Trans and queer culture will be an important component of future work. In the face of a backlash, we are stronger when we are together.

\section{Festheart}

Estonia is currently at a crossroads. Our government is step by step moving towards the "Polish situation". Things are relatively free and "okay" for the moment, but many small steps have been taken in that direction. We see festivals of all kind as important places for the LGBT community to come together and support each other. And for mainstream audiences, film festivals are the perfect place to see that there is nothing weird or terrible about the LGBT+ community.

The situation in Estonia is different than in Sweden, since not that many LGBT+ films even make it to the cinemas, and if they do, then are only screened in Tallinn. We see it as our mission to achieve the same things in Estonia today that were achieved in Sweden and the US 20 years ago. 


\section{REFERENCES}

Berlant, Lauren \& Warner, Michael. 1998. “Sex in Public.” Critical Inquiry 24 (2), $547-566$.

Dawson, Leanne \& Loist, Skadi. 2018. "Queer/ing film festivals: history, theory, impact." Studies in European Cinema I5 (I), I-24.

Edenheim, Sara. 2020. "Queer." lambda nordica 25 (I), II7-I2I.

Muñoz, José Esteban. 2009. Cruising Utopia. The Then and There of Queer Futurity. New York: NYU Press.

\section{NOTE}

I. https://bok-o-bok.com/en/news/side-by-side-opening-stormed-by-police-andsurrounded-by-nationalists 